\title{
INTERNAL CONTROL AND AUDIT OF ENTERPRISES' COMPLIANCE WITH CUSTOMS REQUIREMENTS WHILE CON-DUCTING FOREIGN ECONOMIC ACTIVITY
}

\author{
Olena VAKULCHYK' ${ }^{1}$, Valeriia FESENKO², Oksana KNYSHEK ${ }^{3}$ \\ University of Customs and Finance, Ukraine
}

\begin{abstract}
Evaluation of the reliability of enterprises engaged in the foreign economic activity and simplifying of Customs procedures have become a relevant issue in the context of globalization. The capabilities and preferences of the "Authorized Economic Operator" status are the cause of a new challenge for managers of enterprises - creation of an internal control system to ensure a systematic monitoring of the conditions of Customs compliance standards of reliability and safety, which would allow identifying risks of loss of the "Authorized Economic Operator" status. The purpose of the scientific paper is to improve the internal control system of an enterprise engaged in foreign economic activity in the process of obtaining and saving the "Authorized Economic Operator" status in accordance with the international Custom requirements for safety and reliability. Methodology. The research is based on the methods of logical and analytical modelling of the impact assessment of individual factors on the value of the generalization indicator. The results are tested on the internal accounting data of the existing machine-building enterprises. Results. The paper shows the results of adapting the concept of COSO to the system of internal control of the foreign economic activity of the enterprise in the process of obtaining or retaining the "Authorized Economic Operator" status. The internal control system within the concept of COSO should ensure the achievement of the objectives - operations, reporting, and compliance. The criteria for estimating the objective "compliance" for an enterprise engaged in foreign economic activity can be an integral indicator of compliance. Value/originality. It is suggested to perform internal control of an enterprise's compliance with Customs requirements based on the analysis of deviations of the compliance integral indicator. Practical implications. The result of control is to perform a steady in-crease in the integral index or stable maintenance of the already achieved indicator that will allow a company to maintain the "Authorized Economic Operator" status and perform foreign economic activities with simplified procedures. The indicators of total negative deviations and relative potential of rating are proposed in the paper. Total negative deviations by factors determine the degree of loss of quality characteristics of a company. The indicator of relative potential rating determines the percentage increase in the rating. Results of deviations evaluation by the blocks of the integral index of compliance will allow determining the certain aspect of a company activity, which did not meet Customs standards for the current period, and a responsible person who did not take care about the fulfilment of requirements of Customs standards, which introduces the risk of loss (non-receipt) of the "Authorized Economic Operator" status.
\end{abstract}

Key words: internal control, audit, Authorized Economic Operator, foreign economic activity, customs requirements, Customs standards of reliability and security, compliance control, COSO.

JEL Classification: F10, M21, F20

\section{Introduction}

Intensification of international trade in the context of globalization and the process of implementation of international Custom standards in different countries are stipulating the questions of internal control of compliance with Customs requirements and grade the reliability of companies engaged in international trade.
The most important issue for companies and Customs authorities is the procedures of getting the "Authorized Economic Operator" status. Receiving the status and organization of effective internal control in companiesparticipants of international trade can help them simplify Customs procedures and facilitate the foreign economic activity. The Customs external control of

\footnotetext{
Corresponding author:

${ }^{1}$ Department of Accounting, Audit, Analysis and Taxation, University of Customs and Finance.

E-mail: elvak2016@gmail.com

${ }^{2}$ Department of Accounting, Audit, Analysis and Taxation, University of Customs and Finance.

E-mail: fesenkovalery@i.ua

${ }^{3}$ Department of Accounting, Audit, Analysis and Taxation, University of Customs and Finance.

E-mail: knishek.oksana@gmail.com
} 
the reliability of such companies is important on the one hand but the internal monitoring of compliance with Customs requirements and evaluation of potential losses inside the company are more important from the point of view of the company management staff.

The question of simplification of Customs procedures for companies was studied in the works of Ukrainian researchers (Tereshchenko, 2010), (Vakulchyk, 2014), (Dubitskiy, 2016). The research into internal control procedures and the "Authorized Economic Operator" status indicate that most scientists consider only the problem itself and create the institute of "Authorized Economic Operator" to simplify procedures for foreign trade. The issue of the formation of the internal control system of quality characteristics of a company and its compliance with Customs requirements has not been sufficiently investigated yet.

The scientific originality of this research is that it proposes to improve the internal control over enterprises in order to control their compliance with customs requirements. The control and analysis of compliance of an enterprise with the customs requirements are proposed to be carried out on the basis of analysis of deviations from the integrated compliance indicator. The result of control is to perform a steady increase in the integral index or stable maintenance of the already achieved indicator that will allow a company to maintain the "Authorized Economic Operator" status and perform foreign economic activities with simplified procedures. The indicators of total negative deviations and relative potential of rating are proposed in the paper.

The purpose of the paper is to improve the internal control system of an enterprise engaged in foreign economic activity in the process of obtaining and saving the "Authorized Economic Operator" status in accordance with the international Customs requirements for safety and reliability.

The research is based on the methods of logical and analytical modelling of the impact assessment of individual factors on the value of the generalization indicator. The results are tested on the internal accounting data of the existing machine-building enterprises.

\section{Formation of the system of internal control of the enterprise within the framework of the COSO concept}

At present in many countries, including Ukraine, there are no legislative and regulatory requirements concerning the organization of internal control within enterprises with foreign economic activity. But the international professional community recognized the appropriateness and necessity of implementing an internal control throughout organizations and considers an internal control management system to be an indispensable element of anyorganization. Especially these requirements apply to public companies and companies that enter international markets. There are several international concepts of internal control within organizations, which differ in the subjects of its implementation, components, and targeting. The analysis of existing internal control concepts in the international practice made it possible to determine that each concept has its specific properties depending on the aim of the control. For example, COBIT (Control Objectives for Information and Related Technologies) is oriented to management through information technology and focuses on information security and control. The concept of internal control SAC (control and audit systems) is more focused on supporting internal auditors as representatives of the owners of a company. In addition to international standards of quality control, audits, reviews and other related services, there are assurance requirements for internal control systems of organizations' reporting audited by external auditors. All existing concepts are developed for the use by different persons (internal auditors, external auditors, IT- workers, etc.) and have a lot in common. The concept, which could be a basis for the internal control of the foreign economic activity, is an international concept of internal control by the Committee of Sponsoring Organizations COSO. The latest edition of COSO was described in the document "Integrated Foundation of Internal Controls" in 2013 (COSO, 2013).

The advantage of this concept is focusing on any activity and adaptability to any organization. The internal control system within the COSO concept should ensure the achievement of the objectives operations, reporting, compliance.

Under the COSO concept, an internal control system is a process organized and implemented by the leadership (top management of companies, the board of directors) and other members of an organization in order to provide reasonable assurance of achieving the objectives of internal control (see above). This means that the organization of internal control and its operation is aimed at identifying and eliminating any risks of economic activities that threaten the achievement of those objectives. In our opinion, in this study, it would be appropriate to adapt the COSO concept to the system of internal control of foreign economic activity within an enterprise. This solution will allow controlling the effectiveness of internal control and ensure the confidence of supervisory authorities according to the internationally recognized requirements. The objectives of the internal control under the COSO concept of foreign economic activity are in Figure 1.

Under the COSO concept, the internal control system consists of five elements: control environment, risk assessment, control activities, information and communication, monitoring activities.

To form a proper control environment within the system of internal control of compliance, primarily it is advisable to develop and approve an order of the formation of general concepts (strategy), as well as 


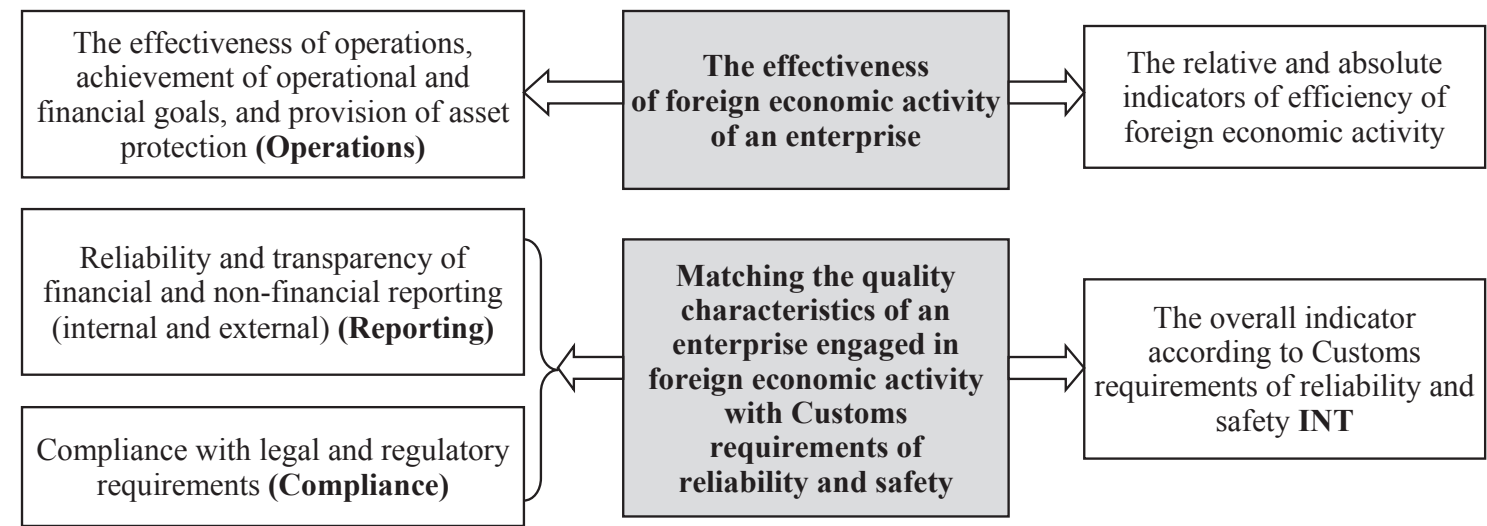

COSO

PURPOSE

\section{CRITERIA}

Fig. 1. The objectives and criteria of internal control under the COSO concept for an enterprise engaged in the foreign economic activity

Source: Elaborated by the authors

control centres responsible for achieving the objectives of foreign trade activity with the adoption of major powers and obligations, first of all, of managerial personnel.

In addition, the organizational structure of a company management should provide centres of responsibility (departments or officials) with a defined list of responsibilities and commitments and targets of their actions.

The environment control is also created to include the main aspects that contribute to a maximum efficiency control:

- an organizational aspect, which is the separation of duties, where internal controllers form the authority to control and have an access to relevant information officers (responsible centres) and assets, as well as the procedure of appointment of internal controllers, the right to choose the procedures and schedule of inspections;

- an economic aspect, which is to build a system of motivation and prevent a participation of controllers in collusion with officials;

- an ethical dimension, that is adherence to the principles of integrity, objectivity, confidentiality and professional competence in accordance with the Code of Ethics for Professional Accountants.

In practice, the organization and control of foreign trade within modern enterprises in Ukraine provide separate centres of responsibility for achieving the planned results or fulfilment of Customs requirements. Building the organizational management structure for the purposes of foreign economic activity should be comprehensive and systematic as well as take into account the following: a general strategy of economic activity, long-term and operational goals of foreign economic activity, performance criteria of foreign economic activity, specific procedures and policies to achieve the objectives, responsibility centres with define responsibilities and obligations as well as relationships between the centres of responsibility.

In our opinion, the above-listed components of the organizational management structure must be clearly spelled out in the relevant orders, which determine the appropriate mechanisms for implementing powers and obligations, as well as stringent criteria for evaluating results and motivation mechanisms.

Risk assessment activities within the system of internal control are implemented by each thematic unit separately and consist of procedures for the identification, evaluation, analysis, and risk management: violation of the law, uncertainty reporting and accounting, loss of ability to pay and deteriorating financial condition, violation of standards of reliability and security, loss of competence. The implementation of this element of the internal control of compliance is ensured by the responsible centres liable for the internal control system.

The element of internal control "Monitoring control procedures" includes requirements to assess whether effective procedures are involved and to what extent the main objectives of internal control are achieved.

\section{Development of a model for analysing deviations from the integral index}

We propose to use the control and analyse deviations from the integral index for an organization to monitor internal control procedures as a part of the internal control of compliance requirements for enterprises.

The integral index of compliance was developed and proposed in the studies of O. Vakulchik and O. Knyshek (3):

$$
\text { INT }=\left(\sum_{j=1}^{d} B_{j}\right) / d \text {, }
$$


where INT - integral index of compliance; $j$ thematic block for evaluation; $B_{j}$ - result of evaluation of the $j$ thematic block of an enterprise; $d$ - number of thematic blocks for the evaluation (there are 5 thematic blocks: compliance with laws and regulations; reporting and accounting; ability to pay and financial status; compliance with safety and security standards; competence and practical skills).

The results of the integral index evaluation allow diagnosing the level of compliance of an enterprise with the eligibility criteria for applicants to be considered an "Authorized Economic Operator". In case of negative assessment results, there are questions of development of management actions to achieve compliance with the trade community safety requirements, in particular, the development of effective monitoring of the implementation of management decisions. Even in case of positive results of the assessment, there is still a question concerning an internal control to maintain the achieved level of enterprise compliance with the standards of reliability and security by all the necessary blocks.

Monitoring compliance with rating evaluation should be aimed at determining the degree of deviation from the requirements (degree of non-compliance with Customs requirements), identification of responsibilities (particular individual decision maker) and the development and implementation of administrative influence on the system of foreign economic activities to address deficiencies of the system.

The result of control is to perform a steady increase in the integral index or stable maintenance of the already achieved indicator that will allow a company to maintain the "Authorized Economic Operator" status and perform foreign trade activities with simplified procedures. The scheme of monitoring compliance with internal control procedures of Customs requirements is presented in Figure 2.

The key issue in the implementation of the monitoring is to determine deviations from the integral index by components (step 3) to identify factors of negative influence and development management decisions to eliminate deviations and ensure sustainable growth value of the integral indicator.

The total deviation integral index can be described by the formula:

$$
\begin{aligned}
& \Delta I N T^{u}=\Delta I N T_{\beta 1}^{u}+\Delta I N T_{\beta 2}^{u}+ \\
& +\Delta I N T_{\beta 3}^{a}+\Delta I N T_{\beta 4}^{a}+\Delta I N T_{\beta 5}^{a} \text {, }
\end{aligned}
$$

where $\triangle I N T a$ - total deviation from the integral indicator for a reporting period (actual) different from the planned (plan), $\Delta I N T_{\beta 1}^{a}$ - deviation from the integral index value due to the violation of legislation in the analysed period (positive or negative), $\Delta I N T^{a}{ }_{\beta 2}-$ deviation from the integral index value due to the failings of the reporting and accounting of goods and vehicles (positive or negative), $\Delta I N T_{\beta 3}^{u}$ - deviation from the integral index value due to deterioration of solvency and financial condition in the analysed period (positive or negative), $\Delta I N T^{a}{ }_{\beta 4}$ - deviation from the integral index value due to non-compliance with safety and security (positive or negative), $\Delta I N T_{\beta 5}^{a}-$ deviation from the integral index value by reducing the level of professional qualifications and competence (positive or negative).

Deviations from the integral indicator value in the reporting period due to variations in the estimates for the components of the integral index are calculated using the formula:

$$
\triangle I N T a \beta j=(\beta j a-\beta j p) / 5 \text {, }
$$

where $\Delta I N T^{a} \beta j$ - deviation from the integral index value by reducing/increasing a component score for the integral index, $j$ - thematic unit integral index (including 5 blocks), $\beta_{j}^{a}$ - actual value of scoring $j$-th component of the integral index, $\beta_{j}^{p}$ - planned importance of scoring the $j$-th component of the integral index.

The results of evaluation of deviations from the integral index for companies are in Table 1. The negative deviation from the integral index shows the

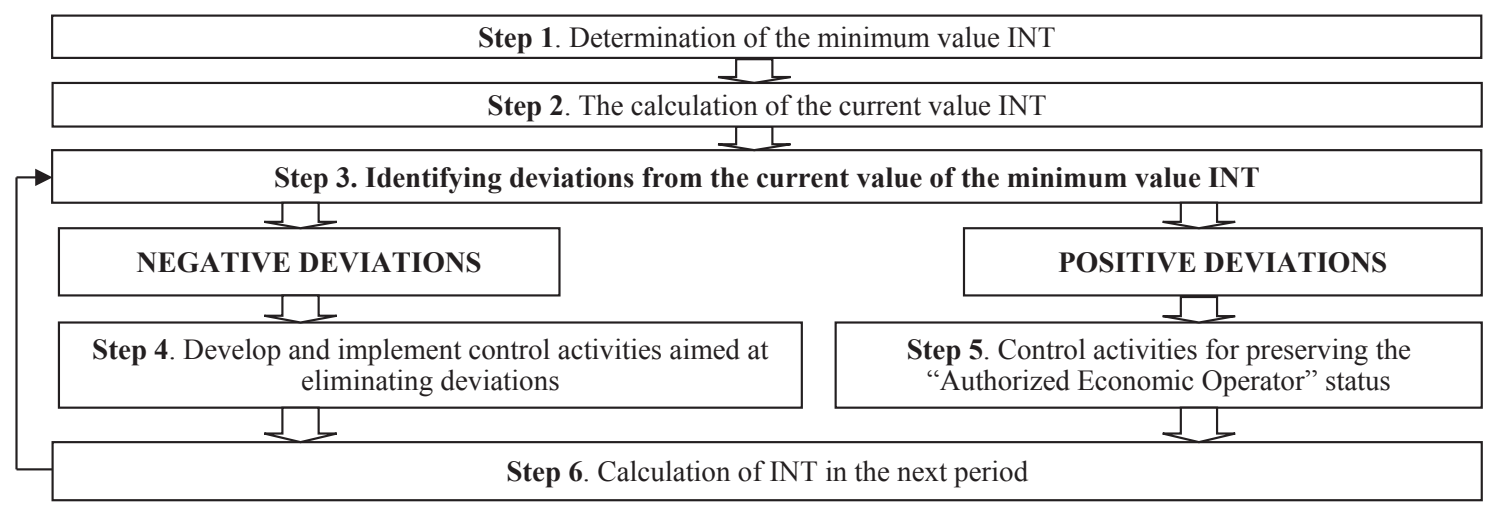

Fig. 2. The monitoring scheme of Customs requirements for the compliance by INT index

Source: Elaborated by the authors 
risk of loss of the "Authorized Economic Operator" status (if the company has already received such a status) or reducing the likelihood of "Authorized Economic Operator" status (if an enterprise expects to receive such status). A positive deviation from the integral index indicates the degree of increase of compliance with Customs requirements. The detailed analysis of variations can provide more relevant information to manage and control parameters of compliance standards.

Definition of deviations from the integral indicator by components allows identifying centres of responsibility and the reasons for non-compliance with Customs diagnostics.

Evaluation results for the deviation units allow determining the aspects of a company, which did not meet Customs standards for the current period and a responsible person who did not provide the requirements of Customs standards. This is the risk of loss (non-receipt) of the "Authorized Economic Operator" status.

Total negative deviations by factors of influence on INT determine the degree of loss of quality characteristics of a company in the current period compared with the basic one, which allows determining INT value a company could reach by means of maintaining quality characteristics at the achieved level. The indicator of relative potential rating determines the percentage increase in the rating of an enterprise's "Authorized Economic Operator" status subject to elimination of negative factors and support of quality characteristics at the achieved level.

For example, for PJSC "Dnipropetrovsk Railway Switch Plant" INT ${ }^{2015}$, it was 2.558 points due to training and professional competence of staff (unit 5). But the level of solvency decreased, which negatively affected the overall integral index. If the management of this company improves the ability to pay and its financial position, the rating of the company will increase by $3.1 \%$ from the already achieved level. A person who can influence the level of solvency and ensure the improvement of the performance is $\mathrm{CFO}$ (a financial manager).

In LC "Kompresormash" the integral index INT ${ }^{2015}$ increased by 0.386 and 2.22 points. The evaluation of deviations shows that there were no negative impacts on the integrated assessment indicator in 2015 and, therefore, it continues applying sufficient management procedures to support the achieved quality characteristics of the company. Companies will be able to achieve an increase in ranking the "Authorized Economic Operator" status by taking additional measures aimed at increasing the level of compliance by the rating units.

\section{Conclusions}

The monitoring of compliance with Customs diagnostics should be aimed at determining the degree of deviation from the requirements (degree of noncompliance with Customs diagnostics), identification of responsibilities (particular individual decision maker) and development and implementation of administrative influence on the system of foreign economic activities to address deficiencies of the system.

The result of control is to perform a steady increase in the integral index of Customs diagnostics or stable maintenance of the already achieved indicator that will allow the company to maintain the "Authorized Economic Operator" status and perform a foreign

Table 1

The results of evaluation of deviations from the integral index for companies

\begin{tabular}{|c|c|c|c|c|c|c|c|c|c|}
\hline \multirow[t]{2}{*}{ Indicators } & \multicolumn{3}{|c|}{$\begin{array}{c}\text { PUBLIC JOINT- } \\
\text { STOCK COMPANY } \\
\text { "DNIPROPETROVSKY } \\
\text { STRILOTCHNY ZAVOD” }\end{array}$} & \multicolumn{3}{|c|}{$\begin{array}{l}\text { LIMITED COMPANY } \\
\text { "COMPRESSORMASH” }\end{array}$} & \multicolumn{3}{|c|}{$\begin{array}{c}\text { PUBLIC JOINT-STOCK } \\
\text { COMPANY “POLTAVA } \\
\text { TURBOMECHANICAL } \\
\text { PLANT” }\end{array}$} \\
\hline & 2013 & 2014 & 2015 & 2013 & 2014 & 2015 & 2013 & 2014 & 2015 \\
\hline INT & 2,36 & 2,438 & 2,558 & 1,862 & 1,834 & 2,22 & 2,08 & 2,192 & 2,34 \\
\hline Deviations: & \multicolumn{2}{|c|}{$2014 / 2013$} & $2015 / 2014$ & \multicolumn{2}{|c|}{$2014 / 2013$} & $2015 / 2014$ & $2014 / 2013$ & \multicolumn{2}{|c|}{$2015 / 2014$} \\
\hline$\Delta I N T_{\beta 1}^{u}$ & \multicolumn{2}{|c|}{$-0,050$} & 0 & \multicolumn{2}{|c|}{$-0,050$} & 0,100 & $-0,100$ & \multicolumn{2}{|c|}{0,050} \\
\hline$\Delta \mathrm{INT}_{\beta 2}^{\mathrm{a}}$ & \multicolumn{2}{|c|}{0,028} & 0 & \multicolumn{2}{|c|}{$-0,058$} & 0,086 & $-0,030$ & \multicolumn{2}{|c|}{0,058} \\
\hline$\Delta \mathrm{INT}_{\beta 3}^{\mathrm{a}}$ & \multicolumn{2}{|c|}{$-0,020$} & $-0,080$ & \multicolumn{2}{|l|}{0} & 0 & $-0,080$ & \multicolumn{2}{|c|}{0,160} \\
\hline$\Delta \mathrm{INT}_{\beta 4}^{\mathrm{a}}$ & \multicolumn{2}{|c|}{0,120} & 0 & \multicolumn{2}{|c|}{0,080} & 0 & 0,120 & \multicolumn{2}{|c|}{0,080} \\
\hline$\Delta \mathrm{INT}_{\beta 5}^{\mathrm{a}}$ & \multicolumn{2}{|l|}{0} & 0,200 & \multicolumn{2}{|l|}{0} & 0,200 & 0,200 & \multicolumn{2}{|c|}{$-0,200$} \\
\hline$\Delta$ INT $^{\mathrm{a}}$ & \multicolumn{2}{|c|}{0,078} & 0,120 & \multicolumn{2}{|c|}{$-0,028$} & 0,386 & 0,110 & \multicolumn{2}{|c|}{0,148} \\
\hline $\begin{array}{l}\text { E negative deviations - risks of losing the } \\
\text { "Authorized Economic Operator" status }\end{array}$ & \multicolumn{2}{|c|}{$-0,070$} & $-0,080$ & \multicolumn{2}{|c|}{$-0,108$} & 0 & $-0,210$ & \multicolumn{2}{|c|}{$-0,200$} \\
\hline \multirow{2}{*}{ INT without negative deviations } & 2014 & & 2015 & 201 & & 2015 & 2014 & & 015 \\
\hline & 2,508 & & 2,638 & 1,94 & & 2,220 & 2,402 & & 540 \\
\hline Relative potential of rating & $2,9 \%$ & & $3,1 \%$ & 5,99 & & 0 & $9,6 \%$ & & $6 \%$ \\
\hline The relative index of lost ranking & $18,7^{\circ}$ & & $14,7 \%$ & 38,9 & & $26 \%$ & $26,9 \%$ & & $2 \%$ \\
\hline
\end{tabular}

Source: Calculated by the authors based on the annual reports of enterprises 
economic activity with simplified procedures. Evaluation results for the deviation units will allow the integral index to determine compliance aspect of the company, which did not meet Customs standards for the current period, and a responsible person who did not provide the requirements of Customs standards, which created the risk of loss (non-receipt) of the "Authorized Economic Operator” status.

\section{References:}

Tereschenko, S., Symonova, H., \& Khablo H. (2010). International standards regarding the status of authorized economic operator. Mytna bezpeka (Customs security), 2, 71-80 (in Ukr.)

Vakul'chyk, O., Knyshek, O., \& Petrosian, A. (2014). Integral assessment of the financial condition of entities in the status of authorized economic operator. Visnyk AMSU (Bulletin of the Academy of Customs Ukraine), 1, 98-105 (in Ukr.)

Vakul'chyk, O., \& Knyshek, O. (2016). Integral-rating evaluation and analysis of qualitative characteristics of the enterprises with international business activity. Ekonomichnyj prostir (Economic space),113, 92-103 (in Ukr.)

Dubitskiy, D., Zhelyakova, A., (2016). Evaluation of the effectiveness of obtaining the status of authorized economic operator. Efekty'vna ekonomika (Efficient economy), 11. Retrieved from: http://www.economy.nayka.com. ua/?op=1\&z=5256 (in Ukr.)

Drej, V. (2013). International regulation of internal audit in enterprises. Ekonomichnyj prostir (Economic space), 80, 167-175 (in Ukr.)

Marchuk, U. (2016). Relationship of operational control and operational accounting. Ekonomichnyj chasopys (Economic Annals), 161 (9-10), 91-94

Committee of sponsoring organizations of the tread way commission. Internal control. Integrated framework. Retrieved from: http://www.coso.org/documents/COSO\%202013\%20ICFR\%20Executive_Summary.pdf

\section{Елена ВАКУЛЬЧИК, Валерия ФЕСЕНКО, ОКсана КНИШЕК}

ВНУТРЕННИЙ КОНТРОЛЬ И АУДИТ СООТВЕТСТВИЯ ПРЕДПРИЯТИЯ ТАМОЖЕННЫМ ТРЕБОВАНИЯ ПРИ ОСУЩЕСТВЛЕНИИ ВНЕШНЕЭКОНОМИЧЕСКОЙ ДЕЯТЕЛЬНОСТИ

Аннотация. Оценка надежности предприятий, занимающихся внешнеэкономической деятельностью и необходимость упрощения таможенных процедур являются актуальной проблемой в контексте глобализации. Возможности и преимущества, которые возникают при получении предприятиями статуса «Уполномоченный экономический оператор» обуславливают формирование новых задач для менеджеров предприятий - создания системы внутреннего контроля для систематического мониторинга соблюдения предприятием таможенных норм по надежности и безопасности. Это позволило бы выявлять риски потери статуса «Уполномоченный экономический оператор». Целью работы является совершенствование системы внутреннего контроля предприятия, занимающегося внешнеэкономической деятельностью, в процессе получения и сохранения статуса «Уполномоченный экономический оператор» в соответствии с международными таможенными требованиями безопасности и надежности. Методика. Исследование основано на методах логического и аналитического моделирования оценки воздействия отдельных факторов на значение обобщающего показателя. Результаты апробированы на внутренних учетных данных существующих машиностроительных предприятий. Результаты. В статье представлены результаты адаптации концепции COSO к системе внутреннего контроля предприятия при совершении внешнеэкономической деятельностью в процессе получения или сохранения статуса «Уполномоченный экономический оператор». Система внутреннего контроля в рамках концепции COSO должна обеспечивать достижение целей по отражению операций, формированию отчетности и соблюдения требований. Значение/оригинальность. Предлагается осуществлять внутренний контроль соответствия предприятия требованиям таможенных органов на основе анализа отклонений интегрального показателя соответствия. Практическое значение. Результатом контроля является постоянное увеличение интегрального индекса или стабильное поддержание уже достигнутого показателя, который позволит компании поддерживать статус «Уполномоченный экономический оператор» и осуществлять внешнеэкономическую деятельность с помощью упрощенных процедур. Суммарное отрицательное отклонение по факторам определяет степень потери качественных характеристик компании. Показатель рейтинга относительного потенциала определяет процентное увеличение рейтинга предприятия. Результаты оценки отклонений по блокам интегрального показателя совместимости позволят определить определенный аспект деятельности компании, который не соответствовал стандартам на текущий период. А также позволит идентифицировать ответственное лицо, которое не обеспечило выполнение требований таможенных стандартов, что приведет к риску потери (не получения) статуса «Уполномоченный экономический оператор». 